Article

\title{
Maternal complications and risk factors for mortality
}

\author{
Sulis Diana, ${ }^{1}$ Chatarina Umbul Wahyuni, ${ }^{2}$ Budi Prasetyo ${ }^{3}$ \\ ${ }^{1}$ Doctoral Program of Public Health; ${ }^{2}$ Department of Epidemiology; ${ }^{3}$ Faculty of Medicine, Airlangga University, \\ Mulyorejo, Surabaya, Indonesia
}

\begin{abstract}
Background: Maternal mortality could be prevented through early detection, including the period preceding pregnancy. Women of childbearing age are faced with extreme uncertainties, hence the purpose of this study was to analyse maternal complications and the possible high-risk factors connected to maternal mortality.

Design and methods: A case-control study was used to study the causes of maternal mortalities amongst pregnant, delivering, and postpartum mothers between 2017 and 2018. A total sample size of 48 samples was selected through simple random sampling.

Results: The result of logistic regression analysis showed nutritional status, prominence of anemia, history of illness, age, antenatal care ANC examination, method of delivery, late referral, occupational status, as well as postpartum complications, as the most influencing risk factors. This very high significance for maternal mortality was based on the chi-square value of 109.431 ( $\mathrm{p}$ equal to 0.000 ), and $\mathrm{R}$ square (0.897).

Conclusions: In conclusion, the potential risk factors of maternal mortality include nutritional status, state of anemia, history of illness, age, ANC examination, delivery method, late referral, occupational status, and pregnancy complications, which is specifically the most dominant factor.
\end{abstract}

\section{Introduction}

Every year, an estimate of 358,000 maternal mortalities is recorded worldwide, with about $99 \%$ cases occurring in poor developing countries, and $67 \%$ reported in a group of eleven countries, which include Indonesia. Moreover there has been an upsurge in the Maternal Mortality Rate (MMR) of East Java from 91.00 to 91.92 per 100,000 live births in 2017 and 2018, respectively. Laksono and Rachmawati reported on 10 preventable cases out of 19 , if recognized prior to the onset of pregnancy. These include women of childbearing age with high risk of being in the unmet need group, consisting of heart disease, breast cancer, HIV/hepatitis, etc. ${ }^{1-4}$

Higher risks of maternal mortality were influenced by factors include low education, lack of prenatal visits, caesarean delivery, haemorrhage, and hypertension. Early screening is expected to reduce maternal mortality rates. ${ }^{3}$ The purpose of this research, therefore, was to analyze the high-risk factors and complications associated with maternal mortality, and to also identify fit/final models with the capacity to predict maternal complications.

\section{Design and methods}

A case-control study was used to study the causes of maternal mortalities amongst pregnant, delivering, and postpartum mothers between 2017 and 2018. A total sample size of 48 cases was selected through simple random sampling. ${ }^{5}$ This study used primary data obtained through interviews and the observation of family members, while discussions regarding the control group were conducted with midwives assisting in the childbirth process. Conversely, the secondary data were obtained from the records on maternal mortalities and antenatal records (KMS), verbal autopsy (OVM), and any other relevant literature. ${ }^{6-9}$ The analytical methods used linear logistic regression.

\section{Results and Discussions}

The result from Table 1 suggested anemia as the leading cause of complications, which was diagnosed in 14 women $(14.3 \%)$. This was followed by labor issues resulting from late referral, reported in $13(13.3 \%)$ cases, and the most significant determinant was that a majority were working mothers, consisting of 71 women $(72.4 \%)$. The results of the Mantel-Haenszel test indicated the characteristics of nutritional status, state of anemia, history of illness, age, ANC examination, method of delivery, late referral and working status as risk factors in maternal mortality (Table 2). ${ }^{10,11}$ Table 3 showed complication in pregnancy as the most dominant factor influencing maternal mortality. This was based on the fact that affected mothers had a $0.3 \%$ higher risk of death than others. ${ }^{12-14}$ The logistic regression analysis (Table 4) attributed a high significance to the model incorporating the influence of

Significance for public health

An upsurge in the maternal mortality rate of East Java indicates maternal health status in this particular area. Reducing maternal mortality is challenging due to the fact that $99 \%$ of maternal mortality occur in low-middle income countries. However, maternal mortality is preventable through early detection of complications and adequate treatment. This study highlights the potential risk factors of maternal mortality, which include nutritional status, state of anemia, history of illness, age, antenatal care (ANC) examination, delivery method, late referral, occupational status, and pregnancy complications. 
Table 1. Risk factors for maternal mortality.

\begin{tabular}{|c|c|c|c|}
\hline Risk factors & Criteria & $\mathrm{N}=98$ & Percentage (\%) \\
\hline Nutritional status & $\begin{array}{l}\text { Good nutrition } \\
\text { Chronic energy deficiency }\end{array}$ & $\begin{array}{l}73 \\
25\end{array}$ & $\begin{array}{l}74.5 \\
25.5\end{array}$ \\
\hline Anemia status & $\begin{array}{l}\text { No anemia } \\
\text { Anemia }\end{array}$ & $\begin{array}{l}84 \\
14\end{array}$ & $\begin{array}{l}85.7 \\
14.3 \\
\end{array}$ \\
\hline History of illness & $\begin{array}{l}\text { No history of illness } \\
\text { With history of illness }\end{array}$ & $\begin{array}{l}68 \\
30\end{array}$ & $\begin{array}{l}69.4 \\
30.6\end{array}$ \\
\hline Age & $\begin{array}{l}\text { Normal }(20-35 \text { years old }) \\
\text { Risky }(<20 \text { years and }>35 \text { years old })\end{array}$ & $\begin{array}{l}76 \\
22\end{array}$ & $\begin{array}{l}77.6 \\
22.4\end{array}$ \\
\hline Parity & $\begin{array}{l}\text { Not risky (2-4) } \\
\text { Risky }\end{array}$ & $\begin{array}{l}77 \\
21\end{array}$ & $\begin{array}{l}78.6 \\
21.4\end{array}$ \\
\hline Pregnancy distance & $\begin{array}{l}\text { Not risky }(>2 \text { years }) \\
\text { Risky }(<2 \text { years })\end{array}$ & $\begin{array}{l}79 \\
19\end{array}$ & $\begin{array}{l}80.6 \\
19.4\end{array}$ \\
\hline ANC examination & $\begin{array}{l}\text { Good ( }>4 \text { times }) \\
\text { Not good }(<4 \text { times })\end{array}$ & $\begin{array}{l}68 \\
30\end{array}$ & $\begin{array}{l}69.4 \\
30.6\end{array}$ \\
\hline Childbirth helper & $\begin{array}{l}\text { Health workers } \\
\text { Non-health workers }\end{array}$ & $\begin{array}{c}98 \\
0\end{array}$ & $\begin{array}{c}100.0 \\
0.0\end{array}$ \\
\hline How to give birth & $\begin{array}{l}\text { Spontaneous } \\
\text { With action }\end{array}$ & $\begin{array}{l}86 \\
12\end{array}$ & $\begin{array}{l}87.8 \\
12.2\end{array}$ \\
\hline Late referrals & $\begin{array}{l}\text { Not late } \\
\text { Late }\end{array}$ & $\begin{array}{l}85 \\
13\end{array}$ & $\begin{array}{l}86.7 \\
13.3\end{array}$ \\
\hline Mother's education & $\begin{array}{l}\text { High school and college } \\
\text { Below middle school }\end{array}$ & $\begin{array}{l}86 \\
12\end{array}$ & $\begin{array}{l}87.8 \\
12.2\end{array}$ \\
\hline Occupational status & $\begin{array}{l}\text { Working } \\
\text { Does not work }\end{array}$ & $\begin{array}{l}71 \\
27\end{array}$ & $\begin{array}{l}72.4 \\
27.6\end{array}$ \\
\hline Place of incident & $\begin{array}{l}\text { House } \\
\text { Public Health Center } \\
\text { Hospital }\end{array}$ & $\begin{array}{c}56 \\
0 \\
42\end{array}$ & $\begin{array}{c}57.1 \\
0.0 \\
42.9\end{array}$ \\
\hline
\end{tabular}

Table 2. Relationship between risk factors and maternal mortality.

\begin{tabular}{|c|c|c|c|c|c|}
\hline Maternal risk factors & Criteria & $\begin{array}{l}\text { Mate } \\
\text { Yes }(\%)\end{array}$ & $\begin{array}{l}\text { ortality } \\
\text { No }(\%)\end{array}$ & Odds ratio (95\% CI) & $\mathbf{R}$ value \\
\hline Nutritional status & $\begin{array}{l}\text { Good nutrition } \\
\text { Chronic energy deficiency }\end{array}$ & $\begin{array}{c}47(94.0 \%) \\
3(6.0 \%)\end{array}$ & $\begin{array}{l}26(54.2 \%) \\
22(45.8 \%)\end{array}$ & $13.256 * *(3.620-48.540)$ & 0.457 \\
\hline Anemia status & $\begin{array}{l}\text { No anemia } \\
\text { Anemia }\end{array}$ & $\begin{array}{l}48(96.0 \%) \\
2(4.0 \%)\end{array}$ & $\begin{array}{l}36(75.0 \%) \\
12(25.0 \%)\end{array}$ & $8.000 * *(1.684-37.997)$ & 0.300 \\
\hline History of illness & $\begin{array}{l}\text { No history of illness } \\
\text { With history of illness }\end{array}$ & $\begin{array}{l}47(94.0 \%) \\
3(6.0 \%)\end{array}$ & $\begin{array}{l}21(43.8 \%) \\
27(56.2 \%)\end{array}$ & $20.143 * *(5.495-73.337)$ & 0.545 \\
\hline Age & $\begin{array}{l}\text { Normal }(20-35 \text { years old }) \\
\text { Risky }(<20 \text { years and }>35 \text { years old })\end{array}$ & $\begin{array}{l}43(86.0 \%) \\
7(14.0 \%)\end{array}$ & $\begin{array}{l}33(68.8 \%) \\
15(31.2 \%)\end{array}$ & $2.792 *(1.022-7.630)$ & 0.207 \\
\hline Parity & $\begin{array}{l}\text { Not risky (2-4) } \\
\text { Risky }\end{array}$ & $\begin{array}{l}42(84.0 \%) \\
8(16.0 \%)\end{array}$ & $\begin{array}{l}35(72.9 \%) \\
13(27.1 \%)\end{array}$ & $1.950(0.726-5.239)$ & 0.135 \\
\hline Pregnancy distance & $\begin{array}{l}\text { Not risky }(>2 \text { years old }) \\
\text { Risky }(<2 \text { years })\end{array}$ & $\begin{array}{l}43(86.0 \%) \\
7(14.0 \%)\end{array}$ & $\begin{array}{l}36(75.0 \%) \\
12(25.0 \%)\end{array}$ & $2.048(0.730-5.747)$ & 0.139 \\
\hline ANC examination & $\begin{array}{l}\text { Good }(>4 \text { times }) \\
\text { Not good }(<4 \text { times })\end{array}$ & $\begin{array}{l}48(96.0 \%) \\
2(4.0 \%)\end{array}$ & $\begin{array}{l}20(41.7 \% \\
28(58.3 \%)\end{array}$ & $33.600 * * 7.302-154.620$ & 0.589 \\
\hline Childbirth helper & $\begin{array}{l}\text { Health workers } \\
\text { Non-health workers }\end{array}$ & $\begin{array}{l}50(51.0 \%) \\
0(0 \%)\end{array}$ & $\begin{array}{c}48(48.0 \%) \\
0(0 \%)\end{array}$ & 0 & 0 \\
\hline How to give birth & $\begin{array}{l}\text { Spontaneous } \\
\text { With action }\end{array}$ & $\begin{array}{l}48(96.0 \%) \\
2(4.0 \%)\end{array}$ & $\begin{array}{l}38(79.2 \%) \\
10(20.8 \%)\end{array}$ & $6.316 * *(1.305-30.562)$ & 0.257 \\
\hline Late referrals & $\begin{array}{l}\text { Not late } \\
\text { Late }\end{array}$ & $\begin{array}{l}48(96.0 \%) \\
2(4.0 \%)\end{array}$ & $\begin{array}{l}37(77.1 \%) \\
11(22.9 \%)\end{array}$ & 7.135 ** $(1.490-34.175)$ & 0.279 \\
\hline Mother's education & $\begin{array}{l}\text { High school and college } \\
\text { Junior high school }\end{array}$ & $\begin{array}{l}45(90 \%) \\
5(10 \%)\end{array}$ & $\begin{array}{l}41(85.4 \%) \\
7(14.6 \%)\end{array}$ & $1.537(0.452-5.221)$ & 0.070 \\
\hline Working status & $\begin{array}{l}\text { Working } \\
\text { Not working }\end{array}$ & $\begin{array}{l}45(90 \%) \\
5(10 \%)\end{array}$ & $\begin{array}{l}26(54.2 \%) \\
22(45.8 \%)\end{array}$ & $7.615^{* *}(2.575-22.525)$ & 0.401 \\
\hline
\end{tabular}


Table 3. Maternal complications and mortality.

\begin{tabular}{lccc}
\hline Types of maternal complications & \multicolumn{2}{c}{ Maternal mortality } & Odds ratio (95\% CI) \\
No complications & $48(96.0 \%)$ & $0(0.0 \%)$ & $540.5 * *(58.195-5020.006)$ \\
Pregnancy complications & $2(4.0 \%)$ & $8(16.7 \%)$ & \\
\hline Labor complications & $0(0.0 \%)$ & $12(25.0 \%)$ & \\
Postpartum complications & $0(0.0 \%)$ & $28(58.3 \%)$ & \\
\hline
\end{tabular}

Table 4. Partial Test Results in Logistic Regression.

\begin{tabular}{|c|c|c|c|c|c|}
\hline Risk factors & B & P value & Exp (B) & & \\
\hline & & & & Lower & Upper \\
\hline Nutritional status (1) & -2.704 & 0.119 & 0.067 & 0.002 & 2.010 \\
\hline State_of_anema (1) & -1.152 & 0.646 & 0.316 & 0.002 & 43.382 \\
\hline History of illness (1) & -2.485 & 0.132 & 0.083 & 0.003 & 2.111 \\
\hline Age (1) & -0.615 & 0.628 & 0.541 & 0.045 & 6.478 \\
\hline Anc examination (1) & -0.644 & 0.657 & 0.525 & 0.031 & 8.989 \\
\hline Delivery method (1) & -1.807 & 0.536 & 0.164 & 0.001 & 49. 991 \\
\hline Late_referral (1) & -1.748 & 0.453 & 0.174 & 0.002 & 16.726 \\
\hline Complications & & 0.002 & b & & \\
\hline Complications (1) & -5.797 & 0.001 & $0.003 * *$ & 0000 & 0.080 \\
\hline Complications (2) & -0.282 & 0.877 & 0.754 & 0.021 & 26.612 \\
\hline Complications (3) & -0.735 & 0.644 & 0.479 & 0.021 & 10.827 \\
\hline Constant & 11.826 & 0.020 & 136814.258 & & \\
\hline
\end{tabular}

nutritional status, state of anemia, disease history, age, ANC examination, delivery method, late referral, occupational status, and postpartum complications with maternal mortality, based on the chi-square value of $109.431 \quad(p=0.000)$. Furthermore, an Nagelkerke R square of 0.897 was also estimated, indicating that $89.7 \%$ of cases were explained by the model variables, while the remaining $11.3 \%$ is due to other factors outside the scope of this research. ${ }^{15-17}$ Meanwhile, a reference to the African governments affiliated the reduction of maternal mortality with an improvement in the upstream predictors, including poor maternal health, poverty, inequality, ${ }^{14}$ and access to quality health services. ${ }^{18-20}$

The prevention of pregnancy complications is actually possible through early detection, conducted by regular and quality examinations, especially for high-risk pregnancies. ${ }^{21}$ This is one of the programs practiced in the Public Health Center, although in a simple way, due to the fact that all pregnancies are basically risky, hence early intervention is important for everyone. ${ }^{22,23}$

The occurrence of high maternal mortality rate in Indonesia is suggestive of low quality health services, and this is assumed impossible to reduce without an effective referral system, especially in cases with complications. ${ }^{24,25}$ Instances where death results from illnesses suffered prior to pregnancy are basically preventable with early detection. This has not been of major concern to health workers conducting antenatal examinations. ${ }^{26}$ However, an observation of the antenatal records (KMS) in the case group findings suggested the absence of any disease history in most deceased patients, while interviews with family and OVM observations showed otherwise. ${ }^{27}$ The results of a research conducted in Madagascar associated some community practices, including women's wages and literacy with reduced maternal mortality. In addition, the other factors include the regular creation of time for hospital visits, and adopting treatment regimen for malaria and tuberculosis. ${ }^{25}$ Meanwhile, there has been an increase in wages and also the level of education by the Indonesian government, hence pregnant women become more aware of the importance of antenatal care and, while delivery is mainly performed at home as a result of sociocultural and religious preferences. However, it also is possible to fight maternal mortality in this region with while recognizing the values and beliefs of women and families. ${ }^{28-30}$

\section{Conclusions}

In conclusion, the potential risk factors of maternal mortality include nutritional status, state of anemia, history of illness, age, ANC examination, delivery method, late referral, occupational status, and pregnancy complications, which is specifically the most dominant factor. 
Correspondence: Chatarina Umbul Wahyuni, Faculty of Public Health, Universitas Airlangga, Kampus C Mulyorejo Surabaya 60115, Indonesia.

Tel: +62315920948 - Fax: +62315924618

E-mail: chatarina.uw@fkm.unair.ac.id.

Key words: Maternal complications; risk factors; mortality

Contributions: All the authors contributed equally.

Disclosure: The authors declare that there is no potential conflict of interest.

Funding: This study was financially supported by Faculty of Public Health, Universitas Airlangga.

Acknowledgements: The authors would like to thank Universitas Airlangga for supporting this research.

Clinical trial: This research has been approved by research ethics commitee of Stikes Majapahit Mojokerto.

Conference presentation: Part of this paper was presented at the 4 th Internasional' Symposium of Public Health, 2019 October 29-31 Griffith Universitas, Gold Coast, Australia.

Received for publication: 6 March 2020.

Accepted for publication: 13 June 2020.

OCopyright: the Author(s), 2020

Licensee PAGEPress, Italy

Journal of Public Health Research 2020;9:1842

doi:10.4081/jphr.2020.1842

This work is licensed under a Creative Commons Attribution NonCommercial 4.0 License (CC BY-NC 4.0).

\section{References}

1. East Java Health Service. Health profile book. Surabaya: East Java Health Office; 2017.

2. Laksono AD, Rachmawati T. Midwife Acceptability in Implementation of Labor Warranty Policy in the District Mojokerto. Buletin Penelitian Sistem Kesehatan 2013;16:3419.

3. Bauserman M, Lokangaka A, Thorsten V, et al. Risk factors for maternal death and trends in maternal mortality in low- and middle-income countries: A prospective longitudinal cohort analysis. Reprod Health 2015; 12:S5.

4. English FA, Kenny LC, McCarthy FP. Risk factors and effective management of preeclampsia. Integr Blood Press Control 2015;8:7-12

5. Kasparis I, Andreou E, Phillips PC. Nonparametric predictive regression. J Econom 2015;185:468-94.

6. Baschat AA. First-trimester screening for pre-eclampsia: moving from personalized risk prediction to prevention. Ultrasound Obstet Gynecol 2015;45:119-29.

7. Cunningham GF, Leveno KJ, Bloom SL, et al. Williams Obstetric Jakarta: EGC; 2013.

8. Davies L, McDonald S. Pemeriksaan kesehatan bayi: Pendekatan multidimensi. Jakarta: EGC; 2011.

9. Rush D. Nutrition and maternal mortality in the developing world. Am J Clin Nutr 2000;72:212S-240S.
10. Bartsch E, Medcalf KE, Park AL, et al. High Risk of Preeclampsia Identification Group. Clinical risk factors for preeclampsia determined in early pregnancy: systematic review and meta-analysis of large cohort studies. BMJ 2016;353: i1753.

11. Aksornphusitaphong A, Phupong V. Risk factors of early and late onset pre-eclampsia. J Obstet Gynaecol Res 2013;39:62731.

12. Kilpatrick SJ, Prentice P, Jones RL, et al. Reducing Maternal Deaths Through State Maternal Mortality Review. J Women's Health 2012;21:905-9.

13. Duckitt K, Harrington D. Risk factors for pre-eclampsia at antenatal booking: Systematic review of controlled studies. BMJ 2005;330:565.

14. Hobel CJ, Hyvarinen MA, Okada DM, et al. Prenatal and intrapartum high-risk screening. Am J Obstet Gynecol 1973;117:19.

15. Wallis AB. Addressing gaps in maternal, neonatal, and child health for achieving SDG 2030 in West Africa. Maternal and Newborn Health 2018;22:9.

16. McCall SJ, Nair M, Knight M. Factors associated with maternal mortality at advanced maternal age: A population-based case-control study. BJOG 2016;124:1225-33.

17. Medforth J, Battersby S, Evans M, et al. Kebidanan Oxford dari bidan untuk bidan. Jakarta: EGC; 2013.

18. Hermandez JC, Moser CM. Community level risk factors for maternal mortality in Madagascar, Afr $\mathrm{J}$ Reprod Health 2013;17:118

19. Azubuke SO, Odagwe NO. Effect of free maternal health services on maternal mortality: An experience from Niger Delta, Nigeria. CHRISMED J Health Res 2015;2:309-15.

20. Abubakar S, Adamu D, Hamza R, et al. Determinants of home delivery among women attending antenatal care in Bagway Town, Kano Nigeria. Afr J Reprod Health 2017;21:73-79.

21. Nyflot L, Sitras V. Strategies To Reduce Global Maternal Mortality. Obstet Gynaecol 2018;97:639-40.

22. Hirshberg AMD, Srinivas SK. Epidemiology of Maternal Morbidity and Mortality. Semin Perinatol 2017;41:332-7.

23. Ozimek JA, Kilpatrick SJ. Maternal Mortality in the TwentyFirst Century. Obstet Gynecol Clin North Am 2018;45:175-86.

24. Howell AE. Reducing Disparities in Severe Maternal Morbidity and Mortality. Clin Obstet Gynecol 2018;61:38799.

25. Geller SE, Koch AR, Garland CE, et al. A Global of View of Severe Maternal Morbidity: Moving Beyond Maternal Mortality. Reprod Health 2018;15:98.

26. MacDorman MF, Declercq E, Thoma ME. Trends in Maternal Mortality by Sociodemographic Characteristics and Cause of Death in 27 States and the District of Columbia. Obstet Gynecol. 2017;129:811-8.

27. Main EK. Reducing Maternal Mortality and Severe Maternal Morbidity Through State-based Quality Improvement Initiatives. Clin Obstet Gynecol 2018;61:319-31.

28. Thaddeus S, Maine D. Too Far To Walk: Maternal Mortality in Context. Soc Sci Med 1994;38:1091-110.

29. Harville EW, Apolzan JW, Bazzano LA. Maternal Pre Pregnancy Cardiovascular Risk Factors and Offspring and Grandoffspring Helath: Bogalusa Daughters. Int J Env Res and Public Health 2019;16:15.

30. Nankali A, Malek-Khosravi Sh, Zangeneh M, et al. Maternal complications associated with severe preeclampsia. J Obstet Gynaecol India 2013;63:112-5. 